Exploring Knowledge Mobilization in Education. URL: https://www.edcan.ca/wp-content/uploads/CEA-2011-Research-Use-1.pdf (accessed: 10.07.2021). [in English].

Rethinking Research for Schools (R4S). URL: http://www.research4schools.org/research/ (accessed: 25.05.2021). [in English].

Partnership for Evidence and Research for Learning Success (PEARLS). URL: https://www.evidenceforlearning.org.au/evidence-informed-educators/collaborative-projects/partnership-for-evidence-and-researchfor-learning-success-pearls/pearls-overview/ (accessed: 25.05.2021). [in English].

Getting Evidence Moving in Schools (GEMS). URL: https://www.evidenceforlearning.org.au/evidence-informed-educators/collaborative-projects/getting-evidence-moving-in-schools-gems/ (accessed: 25.05.2021). [in English].

Sharples, J. (2013). Evidence for the frontline. London: Alliance for Useful Evidence. URL: http://www. alliance4usefulevidence.org/assets/EVIDENCE-FORTHE-FRONTLINE-FINAL-5-June-2013.pdf (accessed: 25.05.2021). [in English].

McLean, R., Graham, I., Tetroe, J.M. et al. (2018). Translating research into action: an international study of the role of research funders. Health Research Policy and Systems. № 16 (44). URL: https://health-policy-systems. biomedcentral.com/articles/10.1186/s12961-018-0316y\#notes (accessed: 25.05.2021). [in English].

Straus, S. E., Tetroe, J., \& Graham, I. (2009). Defining knowledge translation. Canadian Medical Association Journal. № 181(3-4). Pp. 165-168. [in English].

Esmail, R., Hanson, H. M., Holroyd-Leduc, J., Brown, S. et al. (2020). A scoping review of full-spectrum knowledge translation theories, models, and frameworks. Implementation Science. № 15 (1). URL: https://implementationscience. biomedcentral.com/articles/10.1186/s13012-020-0964-5 (accessed: 25.05.2021). [in English].

Graham, I. D., Logan, J., Harrison, M. B., Straus, S. E., Tetroe, J., Caswell, W., \& Robinson, N. (2006). Lost in knowledge translation: time for a map? Journal of Continuing Education in the Health Professions. № 26(1). Pp. 13-24. [in English].

Canadian Institutes of Health Research. (2012). Guide to knowledge translation planning at CIHR: integrated and end-of-grant approaches. URL: https://cihr-irsc.gc. ca/e/45321.html (accessed: 25.05.2021). [in English].

Graham, I. D., Kothari, A. \& McCutcheon, C. (2018). Moving knowledge into action for more effective practice, programmes and policy: protocol for a research programme on integrated knowledge translation. URL: https://implementationscience.biomedcentral.com/articles/10.1186/ s13012-017-0700-y (accessed: 25.05.2021). [in English].

Straus, S. E., Tetroe, J., \& Graham, I. (eds.). (2013). Knowledge Translation in Health Care: Moving from Evidence to Practice. 2nd ed. John Wiley \& Sons. [in English].

Rycroft-Malone, J., Burton, C. R., Wilkinson, J. at al. (2016). Collective action for implementation: a realist evaluation of organisational collaboration in healthcare. Implllementation Science. № 11. URL: https://implementationscience.biomedcentral.com/articles/10.1186/s13012016-0380-z (accessed: 25.05.2021). [in English].

Gifford, W., Graham, I. D., Ehrhart, M. C., Davies, B. L. \& Aarons, G. (2017). Ottawa Model of Implementation Leadership and Implementation Leadership Scale: mapping concepts for developing and evaluating theory-based leadership interventions. Journal of Healthcare Leadership. №9. P.15-23. URL: https://www.ncbi.nlm.nih.gov/pmc/articles/PMC5774448/ (accessed: 25.05.2021). [in English].

Дата надходження до редакиї: 31.05 .2021 р.
УДК 378.091.8:061.2«190/193»

DOI: 10.37026/2520-6427-2021-107-3-9-14

\section{Оксана КОВАЛИШИН,}

кандидат педагогічних наук, асистент кафедри загальної педагогіки та педагогіки вищчої иколи Львівського національного університету імені Івана Франка,

м. Львів, Украӥна

ORCID 0000-0002-7873-5424

e-mail: oksana.i.yarysh@gmail.com

\title{
АКАДЕМІЧНИЙ ДІМ - ОСВІТНЬО-ПРОСВІТНИЦЬКИЙ ОСЕРЕДОК НАУКОВОГО ТОВАРИСТВА ІМЕНІ ШЕВЧЕНКА У ЛЬВОВІ (1905-1939 РОКИ)
}

\author{
Анотація. У статті проаналізована діяльність \\ Академічного дому, створеного при Науковому това- \\ ристві імені Шевченка у Львові (1905-1939 роки), як \\ освітньо-просвітнииького осередку. Схарактеризова- \\ на роль Наукового товариства у начіональному ста-
}

новленні україниів Галичини, відродженні наукового, культурного, освітнього руху та розвитку украӥнської молодіжно-студентської ініціативи. Проаналізовано передумови організації та аспекти функціонування Академічного дому на різних етапах його розвитку. 
Визначено, щзо Наукове товариство імені Шевченка, незважаючи на значну матеріальну скруту, нерентабельність Академічного дому, осуд тодішньої влади, опікувалося та підтримувало освітньо-просвітницький осередок майбутнього покоління україниів.

Закиееттовано увагу на взаємодії Академічного дому з іншими освітніми, культурними та науковими організаціями Галичини у першій третині ХХ століття, зокрема з «Академічною поміччю», Жіночою гімназією сестер Василіянок, товариством «Профорус», "Студентською самопоміччю», Духовною семінарією, Трирічною коедукаиійною торговельною школою та ін. інічіативами. 3'ясовано, шо окрім задоволення нагаль- них потреб оселя відігравала важливу роль у розвитку національного духу, формуванні свідомості студентської молодi.

Констатовано, щчо початок XX століття у Західній Украӥні характеризується розвитком украӥнських громадських організацій, які стали иентрами освітньо-просвітницького, наукового-культурного життя украӥнців. Визначено роль та місие Академічного дому при Науковому товаристві імені Шевченка як головного молодіжно-студентського начіонально-культурного осередку україниів Галичини.

Ключові слова: Академічний дім, освітньо-просвітницький осередок, Наукове товариство імені Шевченка, студентство, молодь, товариство.

\author{
Oksana KOVALYSHYN, \\ Candidate of Pedagogical Sciences, \\ Assistant of the Department of General Pedagogy \\ and Pedagogy of High School \\ Ivan Franko National University of the Lviv, \\ Lviv, Ukraine \\ ORCID 0000-0002-7873-5424 \\ e-mail: oksana.i.yarysh@gmail.com
}

\section{ACADEMIC HOUSE - EDUCATION-ENLIGHTENING CENTER OF SHEVCHENKO SCIENTIFIC SOCIETY IN LVIV (1905-1939)}

\begin{abstract}
Article reveals the activity of the Academic House established by the Shevchenko Scientific Society in Lviv (1905-1939) as an educational and enlightment center. It is described that the activity of the Shevchenko Scientific Society played an important role in the national formation of Ukrainians in Galicia, and it s activity became a mediator in the revival of the scientific, cultural, educational movement and the development of the Ukrainian youth student initiative. It was determined that Shevchenko Scientific Society, despite great financial hardship, unprofitability of the Academic House, condemnation of that time authorities cared for and supported the educational center of the future younger generation of Ukrainians. Analyzed preconditions of the organization and aspects of the functioning of the Academic House during different stages of it's development.

Emphasized the interaction of the Academic House with other educational, cultural and scientific organizations of Galicia in the first third of the twentieth century, in particular with «Academic Aid», Women's Gymnasium SS Vasilianok, Society "Proforus», "Student Self-Help», Theological Seminary, Three-Year schools and others initiatives. It was found that in addition to fulfilling urgent needs, housing played an important role in the development of the national spirit, maintaining the consciousness of student youth.

It has been noted that from the beginning of the Academic House to the Second World War Shevchenko
\end{abstract}

Scientific Society made many efforts to support the Academic House as an important environment for the national development of students, developing talented young people in their desire to get an education and dedicate themselves to serving the Ukrainian people.

Concluded that the beginning of the twentieth century in Western Ukraine characterized by the development of Ukrainian public organizations, which have become centers for educational, scientific and cultural life of Ukrainians. It has been identified role and place of the Academic House at the Shevchenko Scientific Society, as the main youth-student national-cultural center of Ukrainians in Galicia.

Key words: Academic house, educational center, Shevchenko Scientific Society, students, youth, society.

Постановка проблеми. Початок XX століття у Західній Україні характеризується розвитком українських громадських організацій, які стали осередками освітньо-просвітницького, науково-культурного життя українців. Створюючи належні умови для активізації та становлення майбутньої української інтелігенції, захищаючи іiї права та представляючи інтереси перед австрійською і польською владами, українські ініціативи зобов'язалися підтримувати реалізацію освітнього, наукового та культурного потенціалу української молоді. Діяльність таких товариств і громад мала значний вплив на економічне, політичне та духовне життя 
студентської молоді, українську освіту та науку загалом. Важливий внесок у національне становлення українців Галичини зробила діяльність Наукового товариства імені Шевченка (далі - НТШ), активність якого стала посередником у відродженні наукового, культурного, освітнього рухів та розвитку української молодіжно-студентської ініціативи. Саме НТШ, очоливши основний освітньо-просвітницький осередок української молоді - Академічний дім (1905-1939 роки), займалося створенням у Львові сприятливого середовища, взявши під опіку наступні покоління української молоді.

Аналіз наукових досліджень і публікацій. Аналіз наукових джерел свідчить, що історія заснування і діяльності Академічного дому розглядається під призмою загального внеску осередку в освітньо-просвітницьку ситуацію Галичини початку XX ст. Це питання $\epsilon$ предметом дослідження таких науковців, як Т. Брилинський, М. Мороз, В. Мудрий, І. Старовойтенко та ін. Проте основним джерелом вивчення діяльності Академічного дому як освітньо-просвітницького осередку НТШ $є$ архівні документи Центрального державного історичного архіву України у м. Львові (фонди 309, 399, 766 та ін.), Державного архіву Львівської області (фонд 292), часописів та бюлетенів.

Аналізуючи означену наукову проблему, необхідно окремо виділити аспекти заснування та функціонування у Львові Академічного дому, до роботи якого значною мірою долучилося Наукове товариство імені Шевченка.

Метою статті є дослідження діяльності Академічного дому як освітньо-просвітницького осередку, створеного та підтримуваного Науковим товариством імені Шевченка у Львові (1905-1939 роки).

Виклад основного матеріалу дослідження. Історія заснування Академічного дому розпочинається у 1903 році з ініціативи голови Наукового товариства ім. Шевченка М. Грушевського та новоствореного Фонду українського Академічного дому з метою формування осібної оселі для української молоді, що навчалася у закладах вищої освіти Галичини. У 1904 році Виділ НТШ перебрав під своє управління Академічний дім iз сумою 73000 кор. Важливим джерелом цієї фундації став доброчинний внесок визначного українського благодійника С. Чикаленка, що складав 63000 кор., а також долучені внески Наукового товариства імені Шевченка й української громадськості. На ці кошти НТШ було закуплено землю, яка знаходилася близько до львівських закладів вищої освіти.

Напередодні сам М. Грушевський наполягав на задоволенні потреби у матеріальному забезпеченні українського студентства, стверджуючи, що: «найбільше пекуча потреба в сій сфері — се по лїпшеннє матеріяльних обставин нашої академічної молодїжи...» (Грушевський, 1902, с. 52). Тому залишок Академічного фонду, заснованого при НТШ, М. Грушевський хотів передати на заснування осередку для українського студентства, зауважуючи, що роль цього місця є дуже важливою. Означена ініціатива мала б підтримуватися трьома головними освітньо-просвітницькими організаціями Галичини - Науковим товариством імені Шевченка, товариством «Просвіта» та Руським товариством педагогічним.
«Окрім матеріальної користи й були б і моральні. Спільне по житє в такім Академічнім домі причинило ся б до солїдарности, відзвичаювало б від реставрацийного і каварняного житя... студентська їдальня й читальня заступили б місце шиночка й каварнї», так голова НТШ, професор Львівського університету вказував на перехід грошей з Академічного фонду на заснування такого осередку, який би збільшував рівень наукового, освітнього та культурного життя студентів (Грушевський, 1902, с. 53).

19 квітня 1905 року М. Грушевський подав огляд діяльності НТШ, у якому зауважив: «Під заряд свій Виділ із моральних, а не матеріальних мотивів прийняв іще одну інституцію минулого року - Академічний дім... обіцює дуже важні користи нашій академічній молодіжи - тим кругам, з яких рекрутуються наукові робітники нашого Товариства, а тим самим стоіть вона в досить тіснім зв'язку з культурно-науковими цілями нашого Товариства...» (Хроніка НТШ, 1905, Ч. 22, с. 4). Українська молодь для своїх потреб мала спальні кімнати, бібліотеку, читальні, зали для відпочинку, а також кухню. В Академічному домі проживали студенти вищих шкіл Львова за умови наявності довідки 3 місця навчання, автобіографії («Опису життя»), підтвердження бідного соціального становища, а також, що важливо, засвідчення активної роботи студента в будь-якій українській освітньо-просвітницькій організації («Основа», «Рідна школа», читальня «Просвіта», студентський кружок ім. М. Шашкевича тощо) (ДАЛО, Ф. 292, Спр. 22, 53 арк.).

Наукове товариство імені Шевченка стало власником Академічного дому завдяки суспільній повазі до НТШ, а представники самої ініціативи зауважували, що «фундація має ше великі матеріальні зобовязаня, що вона обтяжена значними довгами, що суспільність повина проте памятати про неї і підпирати їі матерільно, бо кожде зменшенє довгу фундації причиниться також до обниженя чиншу студентам, що дасться можність i найбіднішим мешкати здорово та вигідно...» (Хроніка НТШ, 1907, Ч. 29, с. 6).

Крім задоволення важливих фізичних та соціальних потреб, Академічний дім відіграв унікальну роль у плеканні національного духу та піднесенні свідомості української молоді. Із початку його роботи закладалася ідея заснування потужного національного освітньо-просвітницького осередку. В архівних матеріалах 3 цього приводу зазначалося: «Молодіж, будуча суспільна наша, дістає огнище, де може почувати себе у себе дома, де може виховувати своїх членів у здоровій атмосфері праці, висших духовних інтересів, суспільних і національних обов'язків, виміні гадок, і в тім почуттю солідарности й карности, яке дає тілько таке пожитє...» (ДАЛО, Ф. 292, Спр. 5, Арк. 1, 2).

Так, «Академічна поміч» (далі - «А. П.») - українське студентське товариство, що діяло у Львові з 1902 року як «Руська академічна поміч», після 1921 року як «Українська академічна поміч», отримала у найм Академічний дім у 1906 році для того, щоб «винаймати кімнати поодиноким студентам, стягати від них чинш...» (Хроніка НТШ, 1907, Ч. 29, с. 6). Однак цей план виявився фінансово невиправданим і був скасований пізніше, що все ж не завадило студентському 
товариству і надалі підтримувати тісну співпрацю із НТШ (Сваник, 2012, с. 102-103).

Зокрема, підтримувана «Академічною поміччю» «Академічна кухня» (спільна їдальня для української молоді і студентства, організована в Академічному домі) створила анкету для «товаришів» щодо ефективної діяльності з метою подолання дефіциту харчів для учнів та студентів. М. Білецька заохочувала НТШ у матеріальній підтримці «Академічної кухні» (ЦДІА України у м. Львові, Ф. 766, Оп.1, Спр. 4, Арк. 1-4).

У подальшій розбудові інфраструктури Товариства імені Шевченка важливі інституції змінили свою адресну прив'язку незалежно від Академічного дому. На думку В. Дорошенка, Академічний дім від початку заснування «був цілком дефіцитовим підприємством і НТШ мало з ним багато клопоту», а тому у 1907 році з метою зменшення витрат на утримання будинку сюди були перенесені бібліотека та музей Товариства (Дорошенко, 1913, с. 71). Однак у 1912 році бібліотеку і музей із Академічного дому було перенесено у придбаний НТШ будинок по вул. Чарнецького, 24 (Дорошенко, 1913 , с. 70).

Найбільших втрат Академічний дім Наукового товариства імені Шевченка зазнав за часів російської окупації Львова у ході Першої світової війни. Зокрема, Український осередок для молоді та студентства зазнав чималих матеріальних втрат від російських військ, які там розташовувалися та недбало відносилися до майна українців. Означені збитки НТШ не могло покрити для студентського середовища, тому для становлення і реорганізації Академічного дому Товариство імені Шевченка надало 26 червня 1918 року дім у безкоштовну оренду гімназії СС Василіянок.

У червні 1918 року на засіданні Виділу НТШ було прийнято пропозицію директора жіночої гімназії СС Василіянок о. Т. Лежогубського щодо безкоштовної передачі Академічного дому, що був у власності НТШ, на потреби гімназії за умови дотримання певних умов, зокрема: керівництво гімназії мало відреставрувати Академічний дім власним коштом та покривати видатки адміністрації і податки; термін винайму мав тривати 4 роки; частина незайнятих гімназією кімнат передавалася незаможним студентам високих шкіл (Пропам'ятна книга гімназії Сестер Василіянок у Львові, 1980, с. 26-27). Подальше утримання цього будинку мало непросту історію, термін користування ним суттєво змістився і тривав аж до побудови гімназією у 1926 році власного приміщення.

Після Першої світової війни на перших загальних зборах Наукового товариства ім. Шевченка у березні 1921 року було здійснено оцінку матеріального становища Товариства, означено першочергові заходи щодо його діяльності, зокрема питань, що стосувалися функціонування меценатських фондів, функціонування Таємного університету, а також долі Академічного дому, переданого під опіку приватній жіночій семінарії СС Василіянок у Львові (ЦДІА України у м. Львові, Ф. 309, Оп. 1, Спр. 31, Арк. 48, зв. 49).

Слід зазначити, що у міжвоєнний період НТШ доклало чимало зусиль для збереження Академічного дому як важливого осередку національного виховання студентської та учнівської молоді, підтримки талановитої молоді у їі прагненні здобути освіту і присвятити себе служінню рідному народу.

У зазначений період було відновлено діяльність товариства «Академічна поміч», яке 22 квітня 1921 року звернулося до української громадськості за наданням матеріальної допомоги українським студентам: «багато з них не зможе користуватися наукою, якщо не дістане визначної матеріальної діяльності...». Крім того, була зауважена важливість Академічного дому при НТШ як головного осередку студентів у Львові (ЦДІА України у м. Львові, Ф. 766, Оп.1, Спр. 3, Арк. 1). Підтвердженням активної взаємодії «Академічної помочі» з НТШ $є$ факт його прийняття у члени Наукового Товариства «А. П.».

Окремо варто відзначити звернення товариства «Профорус» 12 жовтня 1923 року до НТШ про надання українській студентській молоді, яка навчалася в Українському таємному університеті, Академічного дому для проведення там університетських навчальних лекцій (ЦДІА України у м. Львові, Ф. 309. Оп.1, Спр. 119, Арк. 13-16).

Також вартим уваги є факт підтримки НТШ молодіжної організації «Студентська самопоміч», яка діяла під протекторатом Української крайової студентської ради у Львові. У листі до Виділу НТШ від 18 грудня 1925 року «Самопоміч» підтримувала «Профорус» щодо організації проживання студентської молоді в Академічному домі, адже там мешкали студенти «Академічної громади». У зв’язку з цим «Студентська самопоміч» потребувала рішення від НТШ, яке «не кривдило ні однієї з обох студентських організацій...» (ЦДІА України у м. Львові, Ф. 399, Оп.1, Спр. 163, Арк. 1, 2).

Через брак фінансів і матеріальних ресурсів Наукове товариство імені Шевченка жертвувало Академічним домом на благо української суспільності. Водночас тут неодноразово шукали підтримки українська студентська громада та її організації, зокрема Студентський гурток україністів, Товариство прихильників освіти, Греко-католицька духовна академія, Інтернат для української молоді вищих шкіл (Мороз, 2012, с. 105).

Проаналізуємо ще одну подію, що яскраво засвідчує прихильність НТШ до українського студентства, підтримку ним освітньо-просвітницьких ініціатив. У 1934 році на вимогу Львівського міського староства Товариство прихильників освіти, яке до цього часу патронувало Академічний дім, через підозру у співпраці з українськими націоналістичними організаціями було позбавлене цього права (Хроніка НТШ, 1935, Ч. 72, с. 23-34). Наукове товариство імені Шевченка, незважаючи на велику матеріальну скруту, в черговий раз взяло цей молодіжний осередок під свою опіку. Створений відповідний комітет вжив необхідних заходів щодо виправлення ситуації (ДАЛО, Ф. 292, Спр. 17, Арк. 23).

Попри сумніви окремих членів Товариства щодо доцільності провадити підтримку Академічного дому як «такого собі тягара», дійсний член НТШ І. Свенціцький наголошував, що Академічний дім в умовах заборони польською владою низки українських молодіжних і студентських організацій має бути національним осередком для студентської молоді і завдання Виділу Товариства «поробити у цьому напрямі потрібні заходи» (Хроніка НТШ, 1937, Ч. 73, с. 8-9). 
Із засідання Виділу НТШ 11 грудня 1935 року стало відомо, що Академічний дім орендовано ректором Духовної семінарії на 10 місяців за 650 зл. у місяць. Половина цієї суми призначалася на погашення заборгованості за Академічний дім, а решта - на допомогу бідним студентам високих шкіл (Хроніка НТШ, 1937, Ч. 73, с.15). Із 30 червня 1936 року було продовжено термін винайму Академічного дому для Богословської академії до червня 1937 року за місячну оплату в розмірі 750 зл. (Хроніка НТШ, 1937, Ч. 73, с. 20).

22 травня 1937 року погоджено про те, що Академічний дім НТШ буде винаймати Трирічна коедукаційна торговельна школа товариства «Рідна школа» за 600 зл. у місяць, проте 15 вересня 1937 року Академічний дім вирішила винаймати Екселенція митрополита Шептицького, яка зобов'язалася допомагати українській молоді, що навчалася у високих школах. Зокрема, було відкрито інтернат, який розпочав свою діяльність 1 жовтня 1937 року. Наукове товариство імені Шевченка для цього інтернату віддає Академічний дім безкоштовно за умови утримання і виконання всіх зобов'язань щодо дому (Хроніка НТШ, 1937, Ч. 73 , с. $25-26 ; 46)$.

Висновки. Отже, впродовж діяльності Академічного дому в ньому знайшли прихисток чимало українських організацій та установ, а сам освітньо-просвітницький осередок, створений при НТШ, став місцем національно-визвольних змагань української молоді та студентства.

Таким чином, діяльність Академічного дому як освітньо-просвітницького осередку, створеного при Науковому товаристві імені Шевченка у Львові (1905-1939 роки), була плідна завдяки підтримці української студентської молоді. Спільна співпраця українських громадських організацій («Академічна поміч», Жіноча гімназія СС Василіянок, товариство «Профорус», «Студентська самопоміч», Духовна семінарія, Трирічна коедукаційна торговельна школа та ін.) підтверджувала доцільність створення Академічного дому, що став важливим осередком національного становлення студентської та учнівської молоді, талановитих українців у бажанні здобути освіту та присвятити себе служінню українському народу.

Перспективи подальших досліджень вбачаємо у пошуку методів, форм та засобів підтримки, становлення і взаємодії української прогресивної молоді та студентства 3 українськими освітніми, просвітніми, науковими та культурними організаціями початку XX століття у Західній Україні на шляху здобуття освіти та формування української свідомої інтелігенції.

\section{СПИСОК ВИКОРИСТАНОЇ ЛІТЕРАТУРИ}

Грушевський, М. (1902). Що зробити з «академічним фондом»? Літературно-науковий вісник. Т. 20. Ч. II. C. 52-53.

Хроніка НТШ. (1905). Львів. Ч. 22. С. 4.

Заяви студентів Львівської Політехніки про надання їм житла в Академічному домі з додатком довідок, які засвідчують успіхи у навчанні, участь в громадському житті та матеріальному забезпеченні. (1934) // ДАЛО України. Ф.292. Оп.1. Спр. 22. Арк 53.

Хроніка НТШ (1907). Львів. Ч. 29. С. 6.
Звернення Наукового товариства ім. Шевченка про збирання добровільних пожертвувань на будівництво у Львові Академічного дому та лист уповноваженого громадськості м. Коломиї до Голови НТШ про перекази товариству зібраних на будівництво грошей. (1904) // ДАЛО України. Ф. 292. Оп.1. Спр. 5. Арк. 1, 2.

Сваник, I. (2012). Академічна поміч. Наукове товариство імені Шевченка. Енцииклопедія. А. - Бібл. Т. 1. C. $102-103$.

Лист «Академічної кухні» у Львові до Наукового товариства ім. Т. Шевченка у Львові з проханням надати матеріальну допомогу. (1914) // ЦДІА України у м. Львові. Анкета «Академічної кухні» у Львові. Ф. 766. Оп.1. Спр. 4. Арк. 1-4.

Дорошенко, В. (1913). Наукове Товариство імені Шевченка у Львові (1873-1892-1912). Київ; Львів. C. $70-71$.

Пропам'ятна книга гімназії Сестер Василіянок у Львові. (1980). Нью-Йорк; Париж; Сідней; Торонто. C. $26-27$.

Протоколи загальних зборів. (1903-1940) // ЦДІА України у м. Львові. Ф. 309. Оп. 1. Спр. 31. Арк. 48. зв. 49.

Звернення до української громадськості про надання матеріальної допомоги українським студентам. (1921) // ЦДІА України у м. Львові. Ф. 766. Оп.1. Спр. 3. Арк. 1.

Листи українських студентських організацій «Профорус», «Січ», Спілки студентів у Німеччині про скликання студентського конгресу, передачу приміщень, придбання літератури та ін. (1916-1925) // ЦДІА України у м. Львові. Ф. 309. Оп.1. Спр. 119. Арк. 13-16.

Листи товариства «Студентська самопоміч» Науковому товариству ім. Т. Шевченка у Львові про розв'язання їхнього спору за приміщення по вул. Супінського у Львові. (1925) // ЦДІА України у м. Львові. Ф. 399. Оп.1. Спр. 163. Арк. 1, 2.

Мороз, М. (2012). Академічний дім. Наукове товариство імені Шевченка. Енцииклопедія. А-Бібл. Львів. T. 1. C. 105.

Хроніка НТШ. (1935). Львів. Ч. 72. С. 23-34.

Оголошення «Комітету Академічного дому у Львові». (1929-1934) // ДАЛО України. Ф. 292. Оп.1. Спр. 17. Арк. 23.

Хроніка НТШ. (1937). Львів. Ч. 73. С. 8-46.

\section{REFERENCES}

Hrushevskyi, M. (1902). Shcho zrobyty z «akademichnym fondom»? [What to do with the «academic fund?»]. Literaturno-naukovyi visnyk. T. 20. Ch. II. S. 52-53. [in Ukrainian].

Khronika NTSh [Chronicles SNS]. (1905). Lviv. Ch. 22. S. 4. [in Ukrainian].

Zaiavy studentiv Lvivskoi Politekhniky pro nadannia yim zhytla v Akademichnomu domi z dodatkom dovidok, yaki zasvidchuiut uspikhy u navchanni, uchast $v$ hromadskomu zhytti ta materialnomu zabezpechenni [Statements of students of Lviv Polytechnic on providing them with housing in the Academic House with the addition of certificates certifying success in education, participation in public life and material security]. (1934) // DALO Ukrainy. F.292. Op.1. Spr. 22. Ark 53. [in Ukrainian]. 
Khronika NTSh [Chronicles SNS]. (1907). Lviv. Ch. 29. S. 6. [in Ukrainian].

Zvernennia Naukovoho tovarystva im. Shevchenka pro zbyrannia dobrovilnykh pozhertvuvan na budivnytstvo u Lvovi Akademichnoho domu ta lyst upovnovazhenoho hromadskosti m. Kolomyi do Holovy NTSh pro perekazy tovarystvu zibranykh na budivnytstvo hroshei [Appeal of the Shevchenko Scientific Society on the collection of voluntary donations for the construction of the Academic House in Lviv and a letter from the public commissioner of Kolomyia to the Chairman of the SSS about the transfer of money collected for the construction of the society]. (1904) // DALO Ukrainy. F. 292. Op.1. Spr. 5. Ark. 1, 2. [in Ukrainian].

Svanyk, I. (2012). «Akademichna pomich» [«Academic assistance»]. Naukove tovarystvo imeni Shevchenka. Entsyklopediia. A. - Bibl. T. 1. S. 102-103. [in Ukrainian].

Lyst «Akademichnoi kukhni» u Lvovi do Naukovoho tovarystva im. T. Shevchenka u Lvovi z prokhanniam nadaty materialnu dopomohu [Letter of the «Academic Kitchen» in Lviv to the Shevchenko Scientific Society in Lviv with a request to provide financial assistance. Questionnaire «Academic cuisine» in Lviv]. (1914) // TsDIA Ukrainy u m. Lvovi. Anketa «Akademichnoi kukhnia» u Lvovi. F. 766. Op.1. Spr. 4. Ark. 1-4. [in Ukrainian].

Doroshenko, V. (1913). Naukove Tovarystvo imeni Shevchenka u Lvovi [Shevchenko Scientific Society in Lviv]. (1873-1892-1912). Kyiv; Lviv. S. 70-71. [in Ukrainian].

Propamiatna knyha himnazii Sester Vasyliianok u Lvovi [Commemorative book of the gymnasium of the Basilian Sisters in Lviv]. (1980). Niu-York; Paryzh; Sydnei; Toronto. S. 26-27. [in Ukrainian].

Protokoly zahalnykh zboriv [Minutes of the general meeting]. (1903-1940) // TsDIA Ukrainy u m. Lvovi. F. 309. Op. 1. Spr. 31. Ark. 48 zv.-49. [in Ukrainian].
Zvernennia do ukrainskoi hromadskosti pro nadannia materialnoi dopomohy ukrainskym studentam [Appeal to the Ukrainian public to provide material assistance to Ukrainian students]. (1921) // TsDIA Ukrainy u m. Lvovi. F. 766. Op.1. Spr. 3. Ark. 1. [in Ukrainian].

Lysty ukrainskykh studentskykh orhanizatsii «Proforus», «Sich», Spilky studentiv u Nimechchyni pro sklykannia studentskoho konhresu, peredachu prymishchen, prydbannia literatury ta in. [Letters of Ukrainian student organizations «Proforus», «Sich», the Union of Students in Germany on the convening of a student congress, the transfer of premises, the purchase of literature, etc.] (19161925) // TsDIA Ukrainy u m. Lvovi. F. 309. Op.1. Spr. 119. Ark. 13-16. [in Ukrainian].

Lysty tovarystva «Studentska samopomich» Naukovomu tovarystvu im. T. Shevchenka u Lvovi pro rozviazannia yikhnoho sporu za prymishchennia po vul. Supinskoho u Lvovi [Letters of the Society «Student Self-Help» to the Shevchenko Scientific Society in Lviv on resolving their dispute over the premises on the street Supinsky in Lviv]. (1925) // TsDIA Ukrainy u m. Lvovi. F. 399. Op.1. Spr. 163. Ark. 1, 2. [in Ukrainian].

Moroz, M. (2012). Akademichnyi dim [Academic house]. Naukove tovarystvo imeni Shevchenka. Entsyklopediia. A-Bibl. Lviv. T. 1. S. 105. [in Ukrainian].

Khronika NTSh [Chronicles SNS]. (1935). Lviv. Ch. 72. S. 23-34. [in Ukrainian].

Oholoshennia «Komitetu Akademichnoho domu u Lvovi» [Announcement of the «Committee of the Academic House in Lviv»)]. (1929-1934) // DALO Ukrainy. F. 292. Op.1. Spr. 17. Ark. 23. [in Ukrainian].

Khronika NTSh [Chronicles SNS]. (1937). Lviv. Ch. 73. S. 8-46. [in Ukrainian].

Дата надходження до редакиії: 18.05.2021 p.
УДК 373:613.9

DOI: $10.37026 / 2520-6427-2021-107-3-14-19$

\section{Іван БІЛАВИЧ,}

кандидат педагогічних наук, викладач I клініки анестезіології та інтенсивної терапї

Варшавського медичного університету, м. Варшава, Республіка Польща ORCID: 0000-0003-4561-4690

e-mail:bilawicz@wp.pl

\section{СТАНОВЛЕННЯ І РОЗВИТОК ГІГІЕНІЧНОЇ ПРОСВІТИ ДІТЕЙ ТА ЮНАЦТВА В ЗАКЛАДАХ ОСВІТИ ГАЛИЧИНИ НАПРИКІНЦІ ХІХ - У 30-Х РОКАХ ХХ СТОЛІТЬ}

\begin{abstract}
Анотація. Стаття присвячена гігієнічній просвіті дітей та юнацтва в Галичині наприкінщі XIX-y 30-х рp. XX cm. Крізь призму історичного досвіду висвітлено діяльність інституиій медичного спрямування (Українське гігієнічне товариство, Украӥнське лікарське товариство (УЛТ), «Медична громада», «Народна
\end{abstract}

лічниця»), освітніх, культурно-просвітницьких, жіночих, господарсько-економічних, дитячих і юнацьких, студентських, благодійнииьких, інших громадських організаиій (Украӥнське педагогічне товариство (УПТ) "Рідна школа», «Просвіта», Союз українок, "Сільський господар», "Академічна громада», Товариство 